\title{
Sensitization with Eustrongylides sp. (Nematoda: Dioctophymatidae) antigens induce production of specific IgG and IgE in murine model
}

\author{
Sensibilização com antígenos de Eustrongylides sp. (Nematoda: \\ Dioctophymatidae) induzindo a produção de IgG e IgE em modelo murino
}

Bianca Porto Kuraiem ${ }^{1}$ (1); Maurício Afonso Verícimo ${ }^{2}$ (D); Marcelo Knoff3* (1);

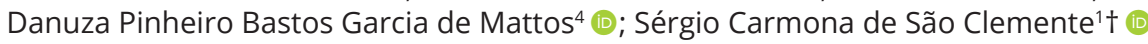

\begin{abstract}
'Laboratório de Inspeção e Tecnologia do Pescado, Faculdade de Medicina Veterinária, Universidade Federal Fluminense - UFF, Niterói, RJ, Brasil

Laboratório de Imunobiologia das Doenças Infecciosas e Granulomatosas, Instituto de Biologia, Universidade Federal Fluminense UFF, Niterói, RJ, Brasil

${ }^{3}$ Laboratório de Helmintos Parasitos de Vertebrados, Instituto Oswaldo Cruz, Fundação Oswaldo CRUZ - FIOCRUZ, Rio de Janeiro, RJ, Brasil

${ }^{4}$ Laboratório de Parasitologia, Instituto Biomédico, Universidade Federal Fluminense - UFF, Niterói, RJ, Brasil
\end{abstract}

How to cite: Kuraiem BP, Verícimo MA, Knoff M, Mattos DPBG, São Clemente SC. Sensitization with Eustrongylides sp. (Nematoda: Dioctophymatidae) antigens induce production of specific IgG and IgE in murine model. Braz J Vet Parasitol 2021; 30(1): e023920. https://doi.org/10.1590/S1984-29612021018

\begin{abstract}
Fish consumption plays an important role in human diet. Hoplias malabaricus, commonly known as traíra, is a freshwater fish widely appreciated in several Brazilian states and frequently infected by Eustrongylides sp. fourthinstar larvae (L4). The aim of the present study was to evaluate allergenic potential of Eustrongylides sp. L4 crude extract (CEE). BALB/c mice were immunized intraperitoneally (IP) by $10 \mu \mathrm{g}$ CEE with $2 \mathrm{mg}$ of aluminum hydroxide on days 0 and 35. Specific IgG and IgE antibody levels were determined after immunization and cellular immunity was evaluated by assessing intradermal reaction in ear pavilion. Epicutaneous sensitization was performed in dorsal region by antigen exposure using a Finn-type chamber containing $50 \mu \mathrm{g}$ of CEE or saline solution, followed by evaluation of specific antibody levels. IP immunization resulted in a gradual increase in IgG antibody levels and transitory IgE production. Significant increase in ear thickness was observed in cellular hypersensitivity reaction. In case of antigen exposure by epicutaneous route, CEE was able to induce meaningfully increased levels of specific IgG and IgE antibodies as well as heightened cellular immunity. Both intraperitoneal immunization and epicutaneous contact with Eustrongylides sp. larval antigens were observed for first time to be capable of inducing immunological sensitization in mice.
\end{abstract}

Keywords: Nematode, allergenic potential, epicutaneous sensitization, intraperitoneal sensitization, murine model.

\section{Resumo}

Consumir peixe constitui papel importante na dieta humana. Hoplias malabaricus, comumente chamado de traíra, peixe de água doce largamente apreciado no Brasil, é frequentemente infectado com larvas de quarto estágio (L4) de Eustrongylides sp. O presente estudo objetivou avaliar o potencial alergênico do Extrato Bruto de L4 de Eustrongylides sp. (EBE). Camundongos BALB/c foram imunizados intraperitonealmente (IP) por $10 \mu \mathrm{g}$ de EBE com 2 mg de hidróxido de alumínio nos dias 0 e 35. Após imunização, determinaram-se níveis específicos de anticorpos IgG e IgE e avaliou-se a imunidade celular pela reação intradérmica no pavilhão auricular. Realizou-se sensibilização epicutânea na região dorsal pela exposição ao antígeno, utilizando-se câmara tipo Finn, contendo $50 \mu \mathrm{g}$ de CEE ou solução salina. Após exposições, foram avaliados níveis específicos de anticorpos. Na imunização

Received October 16, 2020. Accepted February 16, 2021.

*Corresponding author: Marcelo Knoff. E-mail: knoffm@ioc.fiocruz.br

tdeceased in August of 2020.

This is an Open Access article distributed under the terms of the Creative Commons Attribution License, which permits unrestricted use distribution, and reproduction in any medium, provided the original work is properly cited. 
via IP, houve aumento gradual nos níveis de anticorpos IgG e produção de IgE transitória. Foi observado aumento significativo na espessura do pavilhão auricular na reação de hipersensibilidade celular. Na exposição ao antígeno pela via epicutânea, o EBE induziu aumento significante nos níveis de anticorpos IgG e IgE específicos e induziu imunidade celular. Pela primeira vez, observou-se que a imunização intraperitoneal e contato epicutâneo com antígenos larvares de Eustrongylides sp. são capazes de induzir sensibilização imunológica em camundongos.

Palavras-chave: Nematoide, potencial alergênico, sensibilização epicutânea, sensibilização intraperitoneal, modelo murino.

\section{Introduction}

Studies of fish-related allergies have increased in recent years (Davis et al., 2020). Studies examining this phenomenon have shown that allergies are often not related to fish and seafood antigens themselves and may also occur by accidental ingestion of nematode parasite larvae of the family Anisakidae (Nieuwenhuizen et al., 2006).

Another nematode of zoonotic importance, and which has been commonly found parasitizing Hoplias malabaricus (Bloch, 1794), traíra, is Eustrongylides sp. Life cycles of Eustrongylides spp. include multiple hosts; piscivorous birds serve as the terminal host and oligochaetes and small predatory fish act as intermediate hosts (Moravec, 1998; Knoff et al., 2013). Species of the genus Eustrongylides Jägerskiöld, 1909 have been observed parasitizing fish in the United States (Choudhury et al., 2004; Mitchell et al., 2009; Bauer \& Whipps, 2013; McAllister et al., 2016a, b; Muzzall \& Hessenauer, 2018), Mexico (Salgado-Maldonado et al., 2004; Rosas-Valdez et al., 2007; Martínez-Aquino et al., 2012; Pinacho-Pinacho et al., 2014; García-López et al., 2016; Bautista-Hernández et al., 2019; Mosqueda-Cabrera et al., 2019), Argentina (Brugni \& Viozzi, 1999, 2003; Guagliardo et al., 2019), Turkey (Aydoğdu et al., 2011; Çolak, 2013), Italy (Dezfuli et al., 2015; Branciari et al., 2016), Poland (Mierzejewska et al., 2012), Bulgaria (Nachev \& Sures, 2009), Romania (Urdes et al., 2015), Iceland (Kristmundsson \& Helgason, 2007), Serbia (Bjelić-Čabrilo et al., 2013; Djikanović et al., 2018), China (Moravec et al., 2003), Japan (Abe, 2011; Moravec \& Nagasawa, 2018) and Australia (Chapman et al., 2006). In Brazil, Eustrongylides sp. larvae have been reported parasitizing H. malabaricus by several authors (Rego \& Eiras, 1988; Rego \& Vicente, 1988; Barros et al., 2007; Martins et al., 2009; Benigno et al., 2012; Meneguetti et al., 2013; Rodrigues et al., 2017; Kuraiem et al., 2020). Hoplias malabaricus is a predatory fish that feeds on a wide variety of other fish species and inhabits freshwater aquatic ecosystems in Central and South America (Godoy, 1975; Barros et al., 2007; Montenegro et al., 2013).

Human infections caused by the consumption of raw or undercooked fish that have been parasitized by fourthinstar larvae (L4) of Eustrongylides Sp., leading to gastritis and intestinal perforation, have been reported in the United States and South Sudan (CDC, 1982; Gunby, 1982; Eberhard et al., 1989; Wittner et al., 1989; Deardorff \& Overstreet, 1991; Narr et al., 1996; Mitchell et al., 2009; Knoff et al., 2013, Eberhard \& Ruiz-Tiben, 2014).

Human exposure to anisakid nematode larvae has become a prominent public health issue because of its association with allergy symptoms. These symptoms range from localized reactions to generalized manifestations such as allergic rhinitis, conjunctivitis, asthma, urticaria, angioedema, allergic contact dermatitis and anaphylaxis (Armentia et al., 1998; Daschner et al., 2000; Nieuwenhuizen et al., 2006; Audicana \& Kennedy, 2008; Uña-Gorospe et al., 2018).

Anisakis spp. are known to be capable of sensitizing the immune system, resulting in severe allergic and gastrointestinal reactions (Hochberg \& Hamer, 2010; Cho et al., 2014; Morozińska-Gogol, 2019). Recent studies have demonstrated the potential of immunological sensitization in murine model by Contracaecum multipapillatum (Fontenelle et al., 2018) and Hysterothylacium deardorffoverstreetorum (Ribeiro et al., 2017) larvae.

Skin sensitization by food allergens have been reported (Perkin et al., 2020), and antigens applied by the epicutaneous route have been used as potent inducers of food allergies (Wang et al., 1996; Hsieh et al., 2003; Dunkin et al., 2011), suggesting that epicutaneous exposure plays an important role in the cause of atopic allergic dermatitis. For humans, approximately $80 \%$ of patients with atopic dermatitis (AD) have elevated serum levels of total and specific IgE to environmental and/or food allergens (Leung, 2000). Epicutaneous exposure to protein antigens has been reported as one of the important pathways for the development of AD (Santamaria Babi et al., 1995; Teraki et al., 2000). To date, there are no data about the allergenic potential of freshwater fish parasites, such as Eustrongylides sp. In this sense, the present study aimed to analyze the allergenic potential of Eustrongylides sp. larvae, collected from $H$. malabaricus, through sensitization to crude extract by intraperitoneal and epicutaneous routes in a murine model. 


\section{Materials and Methods}

From April, 2016 to April, 2018, 45 specimens of $H$. malabaricus with total length of $13-46 \mathrm{~cm}(24.84 \mathrm{~cm} \pm 7.52)$ and weight of $25-1,110 \mathrm{~g}(220.26 \mathrm{~g} \pm 230.37)$ were collected by local fishermen from the municipality of Magé, in the state of Rio de Janeiro, Brazil $\left(22^{\circ} 39^{\prime} 10^{\prime \prime} \mathrm{S} ; 43^{\circ} 02^{\prime} 26^{\prime \prime} \mathrm{W}\right)$. The fish were transported in isothermal boxes with ice to the Universidade Federal Fluminense (UFF) in the municipality of Niterói, Rio de Janeiro, Brazil, where they were eviscerated and filleted. Parasitic nematodes were removed and observed under an Olympus BX-41 (Tokyo, Japan) brightfield microscope, with identification as Eustrongylides sp. being based on the descriptions of Measures (1988), Moravec (1998) and Kuraiem et al. (2020). All larvae used to prepare crude extract were collected and taxonomically identified by Kuraiem et al. (2020). Samples were washed repeatedly with $0.65 \% \mathrm{NaCl}$ solution and then disintegrated in a Potter homogenizer (Thomas, Philadelphia, USA). Phenylmethylsulphonyl fluoride (PMSF) was then added followed by centrifugation at $10,000 \mathrm{rpm}$ at $4{ }^{\circ} \mathrm{C}$ for 20 minutes. Protein quantification of the extracts was performed by the method of Lowry et al. (1951), using bovine serum albumin (BSA) $1 \mathrm{mg}$ per ml as the standard. For the experiment, 8-10-week-old BALB/c mice were raised and kept in the local bioterium in the Laboratory Animal Nucleus, UFF. This study was approved by the Animal Research Ethics Committee of the Universidade Federal Fluminense (UFF) Centre for Laboratory Animals (1046/ 2018). Immunization with crude extract of Eustrongylides sp. (CEE) involved intraperitoneal injections (IP) with $10 \mu \mathrm{g}$ CEE associated with $2 \mathrm{mg}$ of aluminum hydroxide solution on the initial day of the experiment (day 0 or primary immunization) and on day 35 for an experimental group consisting of five BALB/c mice. Blood samples of the mice were collected on days $0,14,21,35,42,49,63,77,84$ and 91 to determine the levels of specific antibodies in serum using the enzyme-linked immunosorbent assay (ELISA). Sensitization by the epicutaneous route consisted of two experimental groups of five BALB/c mice. The animals were anaesthetized and depilated in the dorsal region on days 0, 7 and 25, for the adhesion of a Finn-type chamber (Finn Chambers ${ }^{\circledR}$, Epitest Ltd Oy, Tuusula, Finland). The control group was exposed to a $0.9 \% \mathrm{NaCl}$ solution and the immunized group was exposed to $50 \mu \mathrm{g}$ CEE. There were three application steps, which took four days each to complete. Blood samples were collected to obtain serum on days 0,28 and 43 to evaluate specific antibody levels by ELISA. The presence of anti-Eustrongylides sp. IgG and IgE isotypes in the sera of mice was determined by ELISA (Verícimo et al., 2015). Briefly, in Nunc MaxiSorp ${ }^{\text {TM }}$ flat-bottom plates (Nunc, Roskilde, Denmark) $50 \mu$ of CEE antigens (containing $20 \mu \mathrm{g}$ protein $/ \mathrm{ml}$ ) were placed in a $0.05 \mathrm{M}$ carbonate/bicarbonate buffer, $\mathrm{pH}$ 9.6. The sera were serially diluted from 1 to 40 in PBS-G (phosphate-buffered saline gelatine, pH 7.2) at base 3 and incubated for $2 \mathrm{~h}$ at $37^{\circ} \mathrm{C}$. After washing with phosphate-buffered saline-Tween (PBS-T), peroxidase-conjugated antibodies anti-total IgG (L and H) (1: 10,000) (rabbit anti-mouse IgG, whole molecule, Sigma-Aldrich, St. Louis, Missouri, USA) were used for $1 \mathrm{~h}$ at $37^{\circ} \mathrm{C}$. The IgE analysis was performed in two steps. First an anti-IgE ( $\varepsilon$ chain) (1:300) (rat antimouse IgE, Invitrogen, Carlsbad, California, USA) for $1 \mathrm{~h}$ at $37^{\circ} \mathrm{C}$, and then, after washing with PBS-T, peroxidaseconjugated antibodies anti-rat IgG (1:10,000) (HRP-goat anti-rat IgG Life Technologies, Carlsbad, California, USA) for $1 \mathrm{~h}$ at $37^{\circ} \mathrm{C}$. After another washing with PBS-T, the reaction with the substrate and chromogen was performed similarly for IgG and IgE by adding $50 \mu \mathrm{l}$ per well of o-phenylenediamine and $\mathrm{H}_{2} \mathrm{O}_{2}$ (diluted in citrate phosphate buffer, pH 5.0) solution (OPD). The enzymatic reaction was stopped with the addition of $4 \mathrm{~N}$ sulphuric acid. Optical density (OD) reading was performed on a microplate reader (Anthos 2010, Krefeld, Germany) at a wavelength of $492 \mathrm{~nm}$. The analysis of the results was performed by comparing the sum of the OD of each serum. The results are reported as arbitrary units of ELISA corresponding to the value of the area under the dilution curve of each serum. For the evaluation of cellular immunity on day 91 (end of the intraperitoneal experiment) and day 43 (end of the epicutaneous experiment), the animals received an intradermal injection of $20 \mu \mathrm{l}$ of CEE in the left ear pavilion and $20 \mu \mathrm{l}$ of $0.90 \% \mathrm{NaCl}$ solution in the right ear pavilion as a control. Ear pavilion thickness was measured before inoculation and at 24, 48 and $72 \mathrm{~h}$ thereafter, with a $\mathrm{n}^{\circ} 7301$ micrometre (Mitutoyo Sul Americana, Rio de Janeiro, Brazil). Data were analysed by repeated measures one-way ANOVA followed with multiple comparisons by post hoc Tukey's, using the program GraphPadPrism-version 6 for Windows XP (GraphPad Software, San Diego, CA, USA, www.graphpad.com Copyright 1992-1998). Values were considered to be significant if $p<0.05$.

\section{Results}

Results of the evaluation of the intensity of the immunological response induced by intraperitoneal route are shown in Figure 1. After primary immunization with CEE, a statistically significant increase in specific IgG antibodies levels (Figure $1 \mathrm{~A}$ ) against CEE occurred on days 14 and 42 when compared to day 0 (control prior to immunization) $(p<0.01$ for day 14 through 35 and $<0.001$ for days 42 through 91). After the second immunization, performed on day 35, an increase in the levels of these antibodies was observed, which remained at the same level until day 91 
Intraperitoneal Sensitization

A

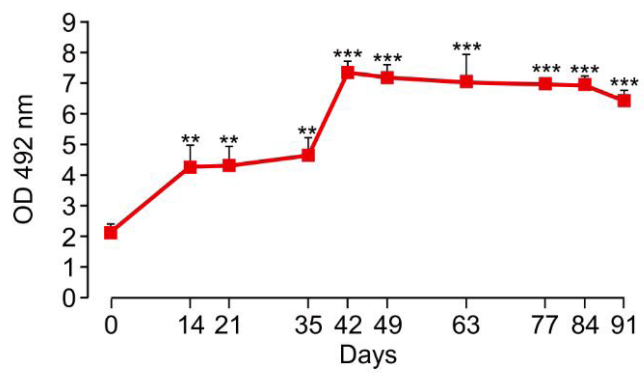

B

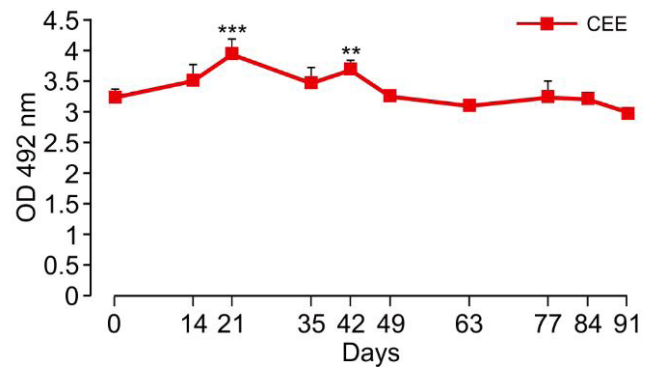

C

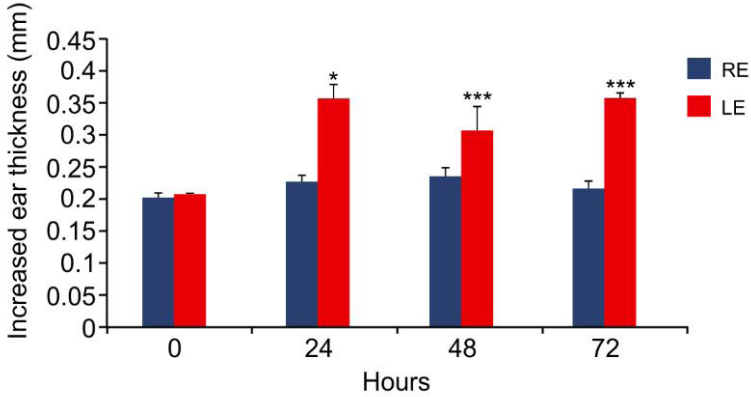

Figure 1. Intraperitoneal sensitization. Immunogenicity of the crude extract of Eustrongylides sp. (CEE). IgG and IgE levels and delayed hypersensitivity reaction. Specific IgG kinetics (A) and specific IgE kinetics (B) for a group of five mice that received intraperitoneal injections of $2 \mathrm{mg}$ of $10 \mu \mathrm{g}$ of CEE associated with $2 \mathrm{mg} \mathrm{Al}(\mathrm{OH})^{3}$ on days 0 and 35 . The values indicate the averages of the sum of the optical densities (OD) \pm the standard deviation (SD) of the group in serum samples at days $0,14,21$, $35,42,49,63,77,84$ and 91; (C) Cell hypersensitivity reaction after challenge with $20 \mu \mathrm{l}$ CEE in the left ear pavilion (LE). The result represents the increase in ear pavilion thickness in millimeters and \pm SD for the LE and the right ear (RE) pavilion as control, at hours $0,24,48$ and $72 .{ }^{*} p<0.05,{ }^{*} p<0.01$ and $* * * p<0.001$, compared to the serum sample taken prior to immunization (Figure 1A, B) and to hour zero (Figure 1C).

$(p<0.001)$. IgE production levels exhibited a transitory elevation at day 21 after the first immunization $(p<0.001)$, and a modest and transitory elevation after the second immunization at day $42(p<0.01)$ (Figure $1 B)$. Evaluation of the cell hypersensitivity reaction is presented in Figure $1 \mathrm{C}$. Cellular immunity revealed a significant increase in ear pavilion thickness when challenged with CEE at hours $24(p<0.05), 48$ and $72(p<0.001)$ compared to hour zero.

The intensity of the immunological response induced by the epicutaneous route is represented in Figure 2 . After sensitization on days 28 and 43 , a significant increase in specific Ig $G$ antibodies against CEE occurred, when compared to the day 0 of the same group ( $p<0.05$ for day 28 and $<0.01$ for day 43) (Figure $2 A$ ). The CEE group presented IgE levels with a transitory elevation at day 28 compared to day 0 of the same group $(p<0.001)$ (Figure $2 B)$. Evaluation of the cell hypersensitivity reaction is presented in Figure $2 \mathrm{C}$. The animals showed a statistically significant increase in left ear pavilion thickness from the initial time until $24 \mathrm{~h}$ had elapsed $(p<0.05)$ with a growth of inflammation at hour 48 and maintenance of the same statistical level of inflammation until hour $72(p<0.001)$ compared to right ear pavilion and hour zero.

\section{Discussion}

The intraperitoneal administration of CEE associated with the immune adjuvant aluminum hydroxide induced the production of IgG and IgE antibodies. This finding is in agreement with experimental immunization for the purpose of inducing high levels of IgE antibodies. Immune-activating immunization requires the combination of the antigen and adjuvants, such as cholera toxin, pertussis toxin or aluminum hydroxide, as reported by Brewer et al. (1999) and Li et al. (2000). In general adjuvants are thought to stimulate certain cell populations involved in antibody responses, and the target of adjuvant effect may vary from one to the other. In this study, was demonstrated that 10 ug the crude extrat derived from fourth-instar larvae from Eustrongylides sp. associated to aluminum hydroxide stimulate an immune response with secretion of high levels of circulating IgG and IgE . 


\section{Epicutaneous Sensitization}

A

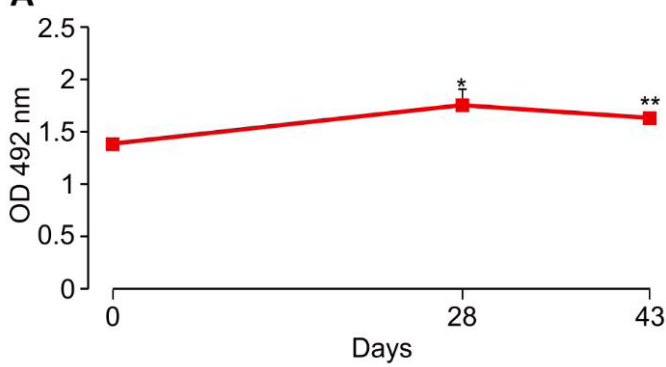

B

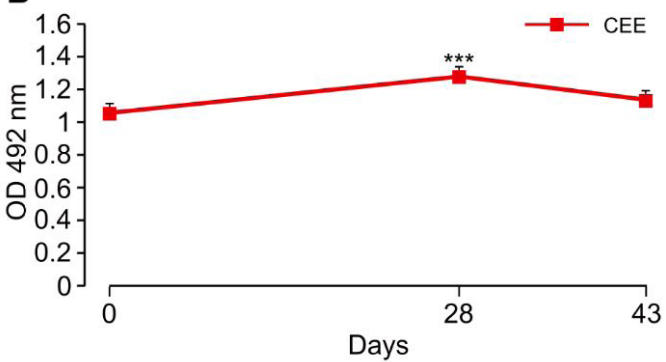

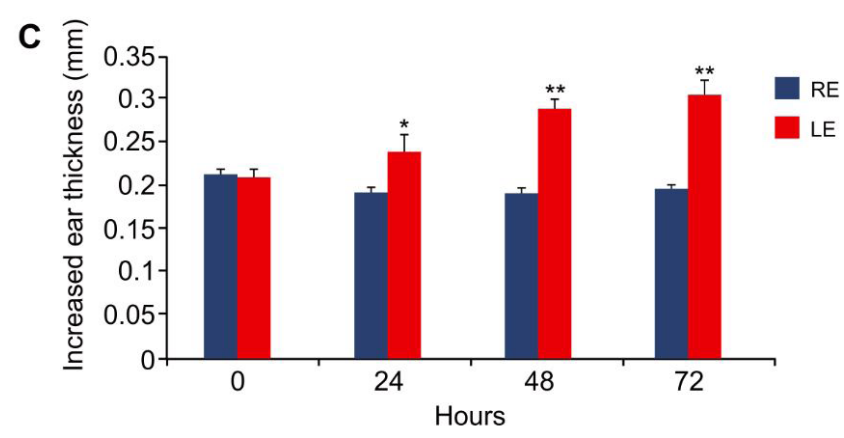

Figure 2. Epicutaneous sensitization. IgG and IgE levels and delayed hypersensitivity reaction. Specific IgG kinetics (A) and specific IgE kinetics (B) for a group of five mice sensitized with $50 \mu \mathrm{g}$ crude extract from Eustrongylides sp. (CEE) via the epicutaneous route on days 0,7 and 25 , Group CEE. The values represent the mean optical density (OD) \pm standard deviation of the group in serum samples at days 0, 28 and 43; (C) Cell hypersensitivity reaction after challenge with $20 \mu$ l CEE in the left ear pavilion (LE). The result represents the increase in ear pavilion thickness in millimeters \pm SD for the LE and right ear (RE) pavilion as control at hours $0,24,48$ and $72 .{ }^{*} p<0.05, * * p<0.01$ and $* * * p<0.001$, compared to the serum sample taken prior to immunization (Figure 2A, B) and to hour zero (Figure 2C).

The result of present study is in agreement with Fontenelle et al. (2018) that challenged mice by intraperitoneal and epicutaneous routes using a crude extract of C. multipapillatum (CECM), an anisakid nematode collected from $H$. malabaricus. These authors reported a significant production of specific IgG and IgE antibodies, which corresponds with the results of the present study by both routes, but they found higher IgG and lower IgE levels, although they used a different parasite and a higher dose of crude extract (50 $\mu \mathrm{g}$ CECM) in their protocol.

Immunization via the intraperitoneal route performed in the present study differs from the experimental protocol developed by Baeza et al. (2005). Using their protocol, these authors were only able to sensitize animals after multiple intraperitoneal inoculations of $100 \mu \mathrm{g}$ of $A$. simplex antigens associated with two adjuvants, aluminum hydroxide and pertussis toxin. The present study demonstrated that utilizing even a small concentration of somatic antigens of Eustrongylides sp. larvae associated with aluminum hydroxide was sufficient to induce specific IgG and IgE antibodies, with a significant increase in the thickness of the ear pavilion of the immunized animals. The present results suggest an immunization with a mixed Th1 / Th2 response, as was suggested by Baeza et al. (2005).

In the present study, a lower concentration of the somatic parasite antigen CEE was effective in initiating IgE production. In comparing the extracts of the two studies (Baeza et al., 2005; Fontenelle et al., 2018), it is important to note that these antigens were extracted from nematode larvae of different families, which could be a reason for the differences in immunological response.

In the present study, the late hypersensitivity reaction was verified by measuring an increase in ear pavilion thickness in the first 24 hours, which can be attributed to the activity of specific antibodies that form immune complexes at the site of the antigen inoculation and alter the vascular permeability and induce the formation of oedema. Also observed in the present study was the maintenance of the thickness of the dermis at 48 and $72 \mathrm{~h}$, which is compatible with mononuclear cell infiltration at the site of inoculation, as reported by Nieuwenhuizen et al. (2006), for reactions of allergic contact dermatitis in humans.

The present study observed low induction of IgE production. This result differs from observations reported by Hsieh et al. (2003), which showed a high induction of IgE production. This difference could come from the longer parasite antigen exposure time (seven days) than that of the present study (four days). 
The results reported here for Eustrongylides sp. and the epicutaneous route show that both triggered an immune sensitization. The possibility, and pathway, of cutaneous hypersensitivity in humans by this nematode should be elucidated in future studies, since this has direct implications for the possible induction of allergy in personnel involved in the preparation of fish for consumption, whether they are an industrial worker, fishmonger or consumer, as suggested by Fontenelle et al. (2018), emphasizing its zoonotic importance.

Both intraperitoneal immunization and epicutaneous contact with Eustrongylides sp. larval antigens were observed for first time to be capable of inducing immunological sensitization in mice. The results obtained in the present study suggest that sensitization of mice with Eustrongylides sp. antigens is capable of inducing sensitization of the immune system. This, in turn, results in considerable antibody production and significant cellular immunity, and further suggests that allergen exposure via the epicutaneous route may be a natural pathway for food allergy sensitization, which can aid in better understanding the pathogenesis of this allergic disease.

\section{Acknowledgments}

The authors would like to thank Heloisa Maria Nogueira Diniz (Serviço de Produção e Tratamento de Imagens, IOC, Fiocruz) for processing the figures, Conselho Nacional de Desenvolvimento Científico e Tecnológico (CNPq) and Coordenação de Aperfeiçoamento de Pessoal de Nível Superior (CAPES) for partial financial supports. This work was supported by CNPq fellowship (SCSC: 308048/2013-0).

\section{References}

Abe N. Molecular and morphological identification of helminthes found in Japanese smelt, Hypomesus transpacificus nipponensis, with notes on new host records of Eustrongylides ignotus and Raphidascaris gigi. Acta Parasitol 2011; 56(2): 227-231. http://dx.doi. org/10.2478/s11686-011-0029-7.

Armentia A, Lombardero M, Callejo A, Martín Santos JM, Gil FJ, Vega J, et al. Occupational asthma by Anisakis simplex. J Allergy Clin Immunol 1998; 102(5): 831-834. http://dx.doi.org/10.1016/S0091-6749(98)70024-7. PMid:9819301.

Audicana MT, Kennedy MW. Anisakis simplex: from obscure infectious worm to inducer of immune hypersensitivity. Clin Microbiol Rev 2008; 21(2): 360-379. http://dx.doi.org/10.1128/CMR.00012-07. PMid:18400801.

Aydoğdu A, Emre Y, Emre N, Altunel FN. The occurrence of helminth parasites (Nemathelminthes) in some freshwater fish from streams discharging into Antalya Bay in Antalya, Turkey: two new host records from Antalya. Turk J Zool 2011; 35(6): 859-864. http://dx.doi.org/10.3906/zoo-0912-16.

Baeza ML, Conejero L, Higaki Y, Martín E, Pérez C, Infante S, et al. Anisakis simplex allergy: a murine model of anaphylaxis induced by parasitic proteins displays a mixed Th/Th pattern. Clin Exp Immuno/ 2005; 142(3): 433-440. http://dx.doi.org/10.1111/j.13652249.2005.02952.x. PMid:16297154.

Barros LA, Moraes Filho J, Oliveira RL. Larvas de nematóides de importância zoonótica encontradas em traíras (Hoplias malabaricus Bloch, 1794) no município de Santo Antônio do Leverger, MT. Arq Bras Med Vet Zootec 2007; 59(2): 533-535. http:// dx.doi.org/10.1590/S0102-09352007000200042.

Bauer EF, Whipps CM. Parasites of Two Native Fishes in Adjacent Adirondack Lakes.J Parasito/ 2013; 99(4): 603-609. http://dx.doi. org/10.1645/GE-3218.1. PMid:23384764.

Bautista-Hernández CE, Pulido-Flores G, Violante-González J, Monks S. Helminth parasites of Xiphophorus birchmanni (Pisces: Poeciliidae) from two localities of the Pánuco River drainage, Mexico. Rev Mex Biodivers 2019; 90(1): e901577. http://dx.doi. org/10.22201/ib.20078706e.2019.90.1577.

Benigno RN, Clemente SC, Matos ER, Pinto RM, Gomes DC, Knoff M. Nematodes in Hoplerytrinus unitaeniatus, Hoplias malabaricus and Pygocentrus nattereri (pisces characiformes) in Marajó Island, Brazil. Rev Bras Parasitol Vet 2012; 21(2): 165-170. http://dx.doi. org/10.1590/S1984-29612012000200018. PMid:22832760.

Bjelić-Čabrilo O, Novakov N, Ćirković M, Kostić D, Popović E, Aleksić N, et al. The first determination of Eustrongylides excisus Jägerskiöld, 1909 - larvae (Nematoda: Dioctophymatidae) in the pike-perch Sander lucioperca in Vojvodina (Serbia). Helminthologia 2013; 50(4): 291-294. http://dx.doi.org/10.2478/s11687-013-0143-1.

Branciari R, Ranucci D, Miraglia D, Valiani A, Veronesi F, Urbani E, et al. Occurrence of parasites of the genus Eustrongylides spp. (Nematoda: Dioctophymatidae) in fish caught in Trasimeno lake, Italy. Ital J Food Saf 2016; 5(4): 6130. http://dx.doi.org/10.4081/ ijfs.2016.6130. PMid:28058245.

Brewer JM, Conacher M, Hunter CA, Mohrs M, Brombacher F, Alexander J. Aluminium hydroxide adjuvant initiates strong antigenspecific Th2 responses in the absence of IL-4-or IL-13-mediated signaling. J Immunol 1999; 163(12): 6448-6454. PMid:10586035. 
Brugni N, Viozzi G. Presencia de Eustrongylides tubifex (Nematoda: Dioctophymatoidea) en la Patagonia, Argentina. Parasitol Latinoam 2003; 58(1-2): 83-85. http://dx.doi.org/10.4067/S0717-77122003000100016.

Brugni NL, Viozzi GP. Presence of Eustrongylides sp. (Jägerskiöld, 1909) (Nematoda: Dioctophymatoidea) in Galaxias maculatus (Jenyns, 1842) (Pisces: Galaxiidae) from Patagonia, Argentina. J Helminthol Soc Wash 1999; 66(1): 92-94.

Centers for Disease Control - CDC. Intestinal perforation caused by larval Eustrongylides - Maryland. MMWR Morb Mortal Wkly Rep 1982; 31(28): 383-389. PMid:6813668.

Chapman A, Hobbs RP, Morgan DL, Gill HS. Helminth parasitism of Galaxias maculatus (Jenyns 1842) in southwestern Australia. Ecol Freshwat Fish 2006; 15(4): 559-564. http://dx.doi.org/10.1111/j.1600-0633.2006.00198.x.

Cho MK, Park MK, Kang SA, Caballero ML, Perez-Pinar T, Rodriguez-Perez R, et al. Allergenicity of two Anisakis simplex allergens evaluated in vivo using an experimental mouse model. Exp Parasitol 2014; 146: 71-77. http://dx.doi.org/10.1016/j. exppara.2014.09.008. PMid:25300761.

Choudhury A, Hoffnagle TL, Cole RA. Parasites of native and nonnative fishes of the little Colorado river, Grand Canyon, Arizona. J Parasitol 2004; 90(5): 1042-1053. http://dx.doi.org/10.1645/GE-3244. PMid:15562604.

Çolak SO. The helminth community of the sand smelt (Atherina boyeri Risso, 1810) from Lake Iznik, Turkey. J Helminthol 2013; 87(2): 129-134. http://dx.doi.org/10.1017/S0022149X11000770. PMid:22189412.

Daschner A, Alonso-Gomez A, Cabañas R, Suarez-De-Parga JM, López-Serrano MC. Gastroallergic anisakiasis: borderline between food allergy and parasitic disease - clinical and allergologic evaluation of 20 patients with confirmed acute parasitism by Anisakis simplex. J Allergy Clin Immunol 2000; 105(1 Pt 1): 176-181. http://dx.doi.org/10.1016/S0091-6749(00)90194-5. PMid:10629469.

Davis CM, Gupta RS, Aktas ON, Diaz V, Kamath SD, Lopata AL. Clinical management of seafood allergy. J Allergy Clin Immunol Pract 2020; 8(1): 37-44. http://dx.doi.org/10.1016/j.jaip.2019.10.019. PMid:31950908.

Deardorff TL, Overstreet RM. Seafood transmitted zoonoses in the United States: the fishes, the dishes, and the worms. In: Ward DR, Hackney CR. Microbiology of marine food products. New York: Van Nostrand Reinhold; 1991. p. 211-265. http://dx.doi. org/10.1007/978-1-4615-3926-1_9.

Dezfuli BS, Manera M, Lorenzoni M, Pironi F, Shinn AP, Giari L. Histopathology and the inflammatory response of European perch, Perca fluviatilis muscle infected with Eustrongylides sp. (Nematoda). Parasit Vectors 2015; 8(1): 227. http://dx.doi.org/10.1186/ s13071-015-0838-x. PMid:25889096.

Djikanović V, Simonović P, Cakić P, Nikolić V. Parasitofauna of allochthonous fish species in the open waters of the Danube river basin (Serbian part) - Impact on the native fish fauna. Appl Ecol Env Res 2018; 16(5): 6129-6142. http://dx.doi.org/10.15666/ aeer/1605_61296142.

Dunkin D, Berin MC, Mayer L. Allergic sensitization can be induced via multiple physiologic routes in an adjuvant-dependent manner. J Allergy Clin Immunol 2011; 128(6): 1251-1258.e2. http://dx.doi.org/10.1016/j.jaci.2011.06.007. PMid:21762973.

Eberhard ML, Hurwitz H, Coletta D, Sun AM. Intestinal perforation caused by larval Eustrongylides (Nematoda: Dioctophymatidae) in New Jersey. Am J Trop Med Hyg 1989; 40(6): 648-650. http://dx.doi.org/10.4269/ajtmh.1989.40.648. PMid:2742040.

Eberhard ML, Ruiz-Tiben E. Cutaneous emergence of Eustrongylides in two persons from South Sudan. Am J Med Hyg 2014; 90(2): 315-317. http://dx.doi.org/10.4269/ajtmh.13-0638. PMid:24379241.

Fontenelle G, Knoff M, Verícimo MA, São Clemente SC. Epicutaneous sensitization with nematode antigens of fish parasites results in the production of specific IgG and IgE.J Helmintho/ 2018; 92(4): 403-409. http://dx.doi.org/10.1017/S0022149X17000633. PMid:28780914.

García-López ML, Salguero-Vargas G, García-Prieto L, Osorio-Sarabia D, Pérez-Ponce de León G. Endohelminths of some species of fishes from Lake Xochimilco, Mexico. Rev Mex Biodivers 2016; 87(4): 1360-1364. http://dx.doi.org/10.1016/j.rmb.2016.06.018.

Godoy MP. Peixes do Brasil. Sub-ordem Characoidei. Bacia do Rio Mogi Guassu. Piracicaba: Ed. Franciscana; 1975.

Guagliardo S, Viozzi G, Brugni N. Pathology associated with larval Eustrongylides sp. (Nematoda: Dioctophymatoidea) infection in Galaxias maculatus (Actinopterygii: Galaxiidae) from Patagonia, Argentina. Int J Parasitol Parasites Wildl 2019; $10(12): 113-116$. http://dx.doi.org/10.1016/j.ijppaw.2019.08.004. PMid:31453085.

Gunby P. One worm in the minnow equals too many in the gut. JAMA 1982; 248(2): 163. http://dx.doi.org/10.1001/ jama.1982.03330020011004. PMid:7087103.

Hochberg NS, Hamer DH. Anisakidosis: perils of the deep. Clin Infect Dis 2010; 51(7): 806-812. http://dx.doi.org/10.1086/656238. PMid:20804423.

Hsieh K-Y, Tsai C-C, Herbert Wu CH, Lin R-H. Epicutaneous exposure to protein antigen and food allergy. Clin Exp Allergy 2003; 33(8): 1067-1075. http://dx.doi.org/10.1046/j.1365-2222.2003.01724.x. PMid:12911780. 
Knoff M, São Clemente SC, Karling LC, Gazarini J, Gomes DC. Helmintos com potencial zoonótico. In: Pavaneli GC, Takemoto RM, Eiras JC, editors. Parasitologia de peixes de água doce do Brasil. Maringá: EDUEM; 2013. p. 17-35.

Kristmundsson A, Helgason S. Parasite communities of eels Anguilla anguilla in freshwater and marine habitats in Iceland in comparison with other parasite communities of eels in Europe. Folia Parasitol (Praha) 2007; 54(2): 141-153. http://dx.doi. org/10.14411/fp.2007.019. PMid:17886743.

Kuraiem BP, Knoff M, Telleria EL, Fonseca MCG, Machado LDS, Cunha NCD, et al. Eustrongylides sp. (Nematoda, Dioctophymatoidea) parasitizing Hoplias malabaricus (Actinopterygii: Erythrinidae) collected from the state of Rio de Janeiro, Brazil. Rev Bras Parasitol Vet 2020; 29(1): e014519. http://dx.doi.org/10.1590/s1984-29612019094. PMid:31778530.

Leung DY. Atopic dermatitis: new insights and opportunities for therapeutic intervention. J Allergy Clin Immuno/ 2000; 105(5): 860-876. http://dx.doi.org/10.1067/mai.2000.106484. PMid:10808164.

Li XM, Serebrisky D, Lee SY, Huang CK, Bardina L, Schofield BH, et al. A murine model of peanut anaphylaxis: t-and B-cell responses to a major peanut allergen mimic human responses. J Allergy Clin Immunol 2000; 106(1): 150-158. http://dx.doi.org/10.1067/ mai.2000.107395. PMid:10887318.

Lowry OH, Rosebrough NJ, Farr AL, Randall RJ. Protein measurement with the Folin phenol reagent. J Biol Chem 1951; 193(1): 265-275. http://dx.doi.org/10.1016/S0021-9258(19)52451-6. PMid:14907713.

Martínez-Aquino A, Pérez-Rodríguez R, Hernández-Mena DI, Garrido-Olvera L, Aguilar-Aguilar R, Pérez-Ponce de León PPG. Endohelminth parasites of seven goodein species (Cyprinodontiformes: Goodeidae) from Lake Zacapu, Michoacán, Central Mexico Plateau. Hidrobiologica 2012; 22(1): 89-93.

Martins ML, Santos RS, Marengoni NG, Takahashi HK, Onaka EM. Seasonality of Eustrongylides sp. (Nematoda: Dioctophymatidae) larvae in fishes from Paraná River, South-western Brazil. Bol Inst Pesca 2009; 35(1): 29-37.

McAllister CT, Bursey CR, Fayton TJ, Cloutman DG, Robison HW, Connior MB, et al. Helminth Parasites of the Blackstripe Topminnow, Fundulus notatus (Cyprinodontiformes: Fundulidae), from Arkansas and Oklahoma, U.S.A. Comp Parasitol 2016a; 83(2): 227-236. http://dx.doi.org/10.1654/4825i.1.

McAllister CT, Bursey CR, Font WF, Robison HW, Trauth SE, Cloutman DG, et al. Helminth Parasites of the Northern Studfish, Fundulus catenatus (Cypriniformes: Fundulidae) from the Ouachita and Ozark Mountains of Arkansas, U.S.A. Comp Parasitol 2016b; 83(1): 78-87. http://dx.doi.org/10.1654/1525-2647-83.1.78.

Measures LN. Revision of the genus Eustrongylides Jägerskiöld, 1909 (Nematoda: Dioctophymatoidea) of piscivorous birds. Can J Zool 1988; 66(4): 885-895. http://dx.doi.org/10.1139/z88-131.

Meneguetti DUO, Laray MPDO, Camargo LMA. Primeiro relato de larvas de Eustrongylides sp. (Nematoda: Dioctophymatidae) em Hoplias malabaricus (Characiformes: Erythrinidae) no Estado de Rondônia, Amazônia Ocidental, Brasil. Rev Pan-Amaz Saúde 2013; 4(3): 55-58. http://dx.doi.org/10.5123/S2176-62232013000300008.

Mierzejewska K, Kvach Y, Woźniak M, Kosowska A, Dziekońska-Rynko J. Parasites of an Asian Fish, the Chinese Sleeper Perccottus glenii, in the Włocławek Reservoir on the Lower Vistula River, Poland: In Search of the Key Species in the Host Expansion Process. Comp Parasitol 2012; 79(1): 23-29. http://dx.doi.org/10.1654/4519.1.

Mitchell AJ, Overstreet RM, Goodwin AE. Eustrongylides ignotus infecting commercial bass, Morone chrysops female X Morone saxatilis male, and other fish in the southeastern USA.J Fish Dis 2009; 32(9): 795-799. http://dx.doi.org/10.1111/j.1365-2761.2009.01051.x. PMid:19490394.

Montenegro AKA, Vieira ACB, Cardoso MML, Souza JERT, Crispim MC. Piscivory by Hoplias aff. malabaricus (Bloch, 1794): a question of prey availability? Acta Limnol Bras 2013; 25(1): 68-78. http://dx.doi.org/10.1590/S2179-975X2013000100008.

Moravec F, Nagasawa K. Rhabdochona angusticaudata sp. n. (Nematoda: Rhabdochonidae) from the Japanese eel Anguilla japonica, and new records of some other nematodes from inland fishes in Japan. Folia Parasito/ 2018; 65(1): 16. https://doi.org/10.14411/ fp.2018.016.

Moravec F, Nie P, Wang G. Some nematodes of fishes from central China, with the redescription of Procamallanus (Spirocamallanus) fulvidraconis (Camallanidae). Folia Parasitol (Praha) 2003; 50(3): 220-230. http://dx.doi.org/10.14411/fp.2003.039. PMid:14535349.

Moravec F. Nematodes of freshwater fishes of the Neotropical region. Praha: Academia; 1998.

Morozińska-Gogol J. Anisakis spp. as etiological agent of zoonotic disease and allergy in European region - an overview. Ann Parasitol 2019; 65(4): 303-314. http://dx.doi.org/10.17420/ap6504.214. PMid:32191412.

Mosqueda-Cabrera MA, Labastida-Valerio JA, Sotelo-Viveros AM, Becerra-García RE, Jiménez-García MI. Helmintos del pez anual Millerichthys robustus (Teleostei: Rivulidae), una especie endémica de México. Rev Mex Biodivers 2019; 90(0): e902652. http:// dx.doi.org/10.22201/ib.20078706e.2019.90.2652. 
Muzzall PM, Hessenauer JM. Parasites of age-0 walleye, Sander vitreus and yellow perch, Perca flavescens (Percidae) from Saginaw Bay, Lake Huron, Michigan, U.S.A. Comp Parasitol 2018; 85(1): 89-94. http://dx.doi.org/10.1654/1525-2647-85.1.89.

Nachev M, Sures B. The endohelminth fauna of barbel (Barbus barbus) correlates with water quality of the Danube River in Bulgaria. Parasitology 2009; 136(5): 545-552. http://dx.doi.org/10.1017/S003118200900571X. PMid:19250599.

Narr LL, O'Donnell JG, Libster B, Alessi P, Abraham D. Eustrongylidiasis: a parasitic infection acquired by eating live minnow. J Am Osteopath Assoc 1996; 96(7): 400-402. http://dx.doi.org/10.7556/jaoa.1996.96.7.400. PMid:8758872.

Nieuwenhuizen N, Lopata AL, Jeebhay MF, Herbert DR, Robins TG, Brombacher F. Exposure to the fish parasite Anisakis causes allergic airway hyperreactivity and dermatitis. J Allergy Clin Immunol 2006; 117(5): 1098-1105. http://dx.doi.org/10.1016/j. jaci.2005.12.1357. PMid:16675338.

Perkin MR, Togias A, Koplin J, Sicherer S. Food allergy prevention: more than peanut. J Allergy Clin Immunol Pract 2020; 8(1): 1-13. http://dx.doi.org/10.1016/j.jaip.2019.11.002. PMid:31950900.

Pinacho-Pinacho CD, Pérez-Ruiz MA, Sereno-Uribe AL, García-Varela M, Martínez-Ramírez E. Richness and similarity of helminth communities of the freshwater fish Profundulus punctatus (Pisces: Cyprinodontidae) from Oaxaca, Mexico. Rev Mex Biodivers 2014; 85(4): 1129-1138. http://dx.doi.org/10.7550/rmb.41776.

Rego AA, Eiras JC. Ecologia da parasitose de peixes e aves do rio Cuiabá (Mato Grosso, Brasil) por Eustrongylides ignotus (Nematoda: Dioctophymidae). Actas Col. Luso-Esp. Ecol. Bacias Hidrogr. e Rec. Zoológicos 1988; 1: 335-341.

Rego AA, Vicente JJ. Eustrongylides ignotus Jagerskiold, 1909 (Nematoda: Dioctophymatoidea), parasito de peixes, anfíbios, répteis e aves. Distribuição e taxonomia. Cienc Cult 1988; 40(5): 478-483.

Ribeiro J, Knoff M, Felizardo NN, Vericimo MA, Clemente SCS. Resposta imunológica a antígenos de Hysterothylacium deardorffoverstreetorum de peixes teleósteos. Arq Bras Med Vet Zootec 2017; 69(2): 422-428. http://dx.doi.org/10.1590/16784162-9383.

Rodrigues LC, Santos ACG, Ferreira EM, Teófilo TS, Pereira DM, Costa FN. Parasitologic aspects of traíra (Hoplias malabaricus) from the São Bento city, MA. Arq Bras Med Vet Zootec 2017; 69(1): 264-268. http://dx.doi.org/10.1590/1678-4162-8798.

Rosas-Valdez R, Domínguez-Domínguez O, Choudhury A, Pérez-Ponce de León PPG. Helminth Parasites of the Balsas Catfish Ictalurus balsanus (Siluriformes: Ictaluridae) in Several Localities of the Balsas River Drainage, Mexico: Species Composition and Biogeographical Affinities. Comp Parasito/ 2007; 74(2): 204-210. http://dx.doi.org/10.1654/4263.1.

Salgado-Maldonado G, Mercado-Silva N, Cabañas-Carranza G, Caspeta-Mandujano JM, Aguilar-Aguilar R, Iñiguez-Dávalos LI. Helminth parasites of freshwater fishes of the Ayuquila River, Sierra de Manantlán biosphere reserve, West Central Mexico. Comp Parasitol 2004; 71(1): 67-72. http://dx.doi.org/10.1654/4067.

Santamaria Babi LF, Picker LJ, Perez Soler MT, Drzimalla K, Flohr P, Blaser K, et al. Circulating allergen-reactive T cells from patients with atopic dermatitis and allergic contact dermatitis express the skin-selective homing receptor, the cutaneous lymphocyteassociated antigen. J Exp Med 1995; 181(5): 1935-1940. http://dx.doi.org/10.1084/jem.181.5.1935. PMid:7722470.

Teraki Y, Hotta T, Shiohara T. Increased circulating skin-homing cutaneous lymphocyte-associated antigen (CLA)+ type 2 cytokineproducing cells, and decreased CLA+ type 1 cytokine-producing cells in atopic dermatitis. Br J Dermatol 2000; $143(2)$ : $373-378$. http://dx.doi.org/10.1046/j.1365-2133.2000.03665.x. PMid:10951148.

Uña-Gorospe M, Herrera-Mozo I, Canals ML, Martí-Amengual G, Sanz-Gallen P. Occupational disease due to Anisakis simplex in fish handlers. Int Marit Health 2018; 69(4): 264-269. http://dx.doi.org/10.5603/IMH.2018.0042. PMid:30589066.

Urdes LD, Marin MP, Diaconescu C, Nicolae CG, Hangan M. Diaconescu C, Nicolae CG, Hangan M. First case report of Eustrongylidosis in eel (Anguilla anguilla) populations inhabiting Danube Delta lakes. Agric Agric Sci Procedia 2015; 6: 277-280. http://dx.doi.org/10.1016/j.aaspro.2015.08.072.

Vericimo MA, Figueiredo I, Teixeira GA, Clemente SC. Experimental anisakid infections in mice.J Helmintho/ 2015; 89(5): 620-624. http://dx.doi.org/10.1017/S0022149X14000340. PMid:24780178.

Wang LF, Lin JY, Hsieh KH, Lin RH. Epicutaneous exposure of protein antigen induces a predominant Th2-like response with high IgE production in mice. J Immunol 1996; 156(11): 4077-4082. PMid:8666772.

Wittner M, Turner JW, Jacquette G, Ash LR, Salgo MP, Tanowitz HB. Eustrongylidiasis - a parasitic infection acquired by eating sushi. N Engl J Med 1989; 320(17): 1124-1126. http://dx.doi.org/10.1056/NEJM198904273201706. PMid:2710174. 